\title{
Effects of Different Fertilizing Formulae on Potato
}

\author{
Giovanna Cucci*, Giovanni Lacolla \\ Dipartimento di Scienze delle Produzioni Vegetali, Università di Bari \\ Via Amendola, 165/A, 70126 Bari, Italy
}

Received: 23 February 2006. Accepted: 5 May 2006.

\begin{abstract}
Trials conducted on potato fertilization at different rates of nitrogen, phosphorus and potassium have shown that the elements able to influence the marketable tuber yield are nitrogen and phosphorus. The potato dry matter, which reflects other quality aspects such as the specific gravity and the starch content, increases with nitrogen fertilization till 150-200 $\mathrm{kg} \mathrm{ha}^{-1}$ of nitrogen; beyond those rates values remain nearly unchanged. Dry matter increases also with the application of phosphorus and at low potassium rates. The objective of the research was to test the effect of different rates of N P K fertilizer on yield and some quality traits of potato.

The test was conducted at the Campus of the Agricultural Faculty, Bari University, Italy. It involved the comparison of 6 fertilizing formulae $\mathrm{N}_{1} \mathrm{P}_{1} \mathrm{~K}_{1}, \mathrm{~N}_{1} \mathrm{P}_{2} \mathrm{~K}_{1}, \mathrm{~N}_{2} \mathrm{P}_{1} \mathrm{~K}_{1}, \mathrm{~N}_{2} \mathrm{P}_{2} \mathrm{~K}_{1}, \mathrm{~N}_{3} \mathrm{P}_{1} \mathrm{~K}_{1}, \mathrm{~N}_{3} \mathrm{P}_{2} \mathrm{~K}_{1}$, obtained from the factorial combination of three nitrogen levels $\left(\mathrm{N}=100-200-300 \mathrm{~kg} \mathrm{ha}^{-1}\right)$ and two phosphorus rates $\left(\mathrm{P}_{2} \mathrm{O}_{5}=50-100 \mathrm{~kg} \mathrm{ha}^{-1}\right)$ against an unfertilized control $\mathrm{N}_{0} \mathrm{P}_{0} \mathrm{~K}_{0}$. The dose of potassium was constant for all fertilizing formulae $\left(\mathrm{K}_{2} \mathrm{O}=300\right.$ $\mathrm{kg} \mathrm{ha}^{-1}$ ).

The highest total and marketable yields of tubers per plant have been observed at the two highest fertilizing levels $\left(\mathrm{N}_{3} \mathrm{P}_{1} \mathrm{~K}_{1}, \mathrm{~N}_{3} \mathrm{P}_{2} \mathrm{~K}_{1}\right)$, which are not statistically different so that the best treatments is shown to be $\mathrm{N}_{3} \mathrm{P}_{1} \mathrm{~K}_{1}$; the trend was similar for the mean weight of tubers. With the various treatments, no difference was observed in terms of yield of tubers belonging to the two first size classes $(<35 \mathrm{~mm}$ and $35-55 \mathrm{~mm})$; what has increased with the fertilizing levels is the yield of tubers greater than $55 \mathrm{~mm}$. Tuber specific gravity show, as expected, a positive correlation with the dry matter percentage. Both parameters increased shifting from the control to the $\mathrm{N}_{2} \mathrm{P}_{2} \mathrm{~K}_{1}$ and decreased at the highest $\mathrm{N}$ level, without any difference being observed with the change in the $\mathrm{P}$ rate. The highest starch percentage $(20.5 \%)$ was also observed in the crop fertilized by $\mathrm{N}_{2} \mathrm{P}_{2} \mathrm{~K}_{1}$.

Yield and yield components increase with the application of nitrogen fertilizer and do not change when applying high rates of phosphorus. The tubers with the highest specific gravity and starch content values are obtained when applying respectively 200 and $50 \mathrm{~kg} \mathrm{ha}^{-1}$ of nitrogen and phosphorus.
\end{abstract}

Key-words: Potato, N P K rates, yield parameters, specific gravity.

\section{Introduction}

Fertilization is one of the agricultural techniques for which the use of more sustainable practices is nowadays a must. The traditional fertilization prescriptions are thus to be re-considered taking into account their environmental impact and the progressive need to reduce farm costs (Grignani et al., 2003). The mineral nutrition is known to influence both the metabolic processes and the amount of nutrients existing in the plant in the form available to humans (Bianco, 1990). Trials conducted on potato fertilization at different rates of nitrogen, phos- phorus and potassium have shown that the elements able to influence the marketable tuber yield are nitrogen and phosphorus. The nitrogen effectiveness acts through the increase in both the number and mean weight of tubers per plant; the action of phosphorus is instead more evident on the number of produced tubers rather than on their weight (Piazza and Venturi, 1973). In general, nitrogen and potassium favour the formation of tubers greater than $35 \mathrm{~mm}$ (Gravoueille, 1987). The potato dry matter, which reflects other quality aspects such as the specific gravity and the starch content, increases with nitrogen fertilization till $150-200 \mathrm{~kg} \mathrm{ha}^{-1}$ 
of nitrogen; beyond those rates values remain nearly unchanged. Dry matter increases also with the application of phosphorus (Shevchenko and Sidoreko, 1976) and at low potassium rates, whereas it decreases at high potassium rates (Muller, 1988). Specific gravity, which is positively correlated with the dry matter in potato tubers, decreases progressively with increasing potassium rates and - beyond a given threshold with the increases of nitrogen rates (Kunkel and Holstad, 1972). The starch content is also largely affected by fertilization; actually as the nitrogen availability increases in the soil, nitrogen has been shown to decrease progressively in the soil (Leszcynski and Lisinska, 1988). According to Marshner and Krauss (1980) P and K also seem to reduce starch content. For further contributing to the knowledge of these problems a research has been conducted at the Department of Plant Production Science of Bari University (Italy) to test the effects of different rates of formulae N P K fertilizers on potato crop.

\section{Materials and methods}

The research was conducted at the experimental field next to the Agricultural Faculty of Bari University (Italy), in plastic pots (height $0.60 \mathrm{~m}$ and diameter $0.72 \mathrm{~m}$ ), equipped at the bottom with a tap to collect drainage water) filled with silty-clay soil of good fertility whose main properties are shown in Table 1.

Six fertilizer treatments: $\mathrm{N}_{1} \mathrm{P}_{1} \mathrm{~K}_{1}, \mathrm{~N}_{1} \mathrm{P}_{2} \mathrm{~K}_{1}$, $\mathrm{N}_{2} \mathrm{P}_{1} \mathrm{~K}_{1}, \mathrm{~N}_{2} \mathrm{P}_{2} \mathrm{~K}_{1}, \mathrm{~N}_{3} \mathrm{P}_{1} \mathrm{~K}_{1}, \mathrm{~N}_{3} \mathrm{P}_{2} \mathrm{~K}_{1}$, obtained from the factorial combination of $3 \mathrm{~N}$ rates (100-200-300 kg ha $\left.{ }^{-1}\right)$ and $2 \mathrm{P}$ rates $\left(\mathrm{P}_{2} \mathrm{O}_{5}=50\right.$ $\left.100 \mathrm{~kg} \mathrm{ha}^{-1}\right)$, were compared against an unfertilised control $\left(\mathrm{N}_{0} \mathrm{P}_{0} \mathrm{~K}_{0}\right)$. The $\mathrm{K}$ rate was the same for all treatments $\left(\mathrm{K}_{2} \mathrm{O}=300 \mathrm{~kg} \mathrm{ha}^{-1}\right)$.

The randomised block design was used with four replicates for a total of 56 pots.

The treatments were studied within a comparative trial between 2 two-year rotations (potato - wheat + bean; potato + purslane wheat + bean) aimed at testing the purslane potential and its ability to use the available residual nitrogen after potato cropping to reduce deep percolation losses.

Potato (cv Nicola) ware planted on 23 february 2000 at a density of 4.19 tubers $\mathrm{m}^{-2}$, placing 2 tubers per pot at a $0.30 \mathrm{~m}$ spacing.
Tables 1. Main properties of the soils.

\begin{tabular}{|c|c|}
\hline \multicolumn{2}{|l|}{ Chemical properties: } \\
\hline Total Nitrogen (Kjeldahl meth.) (\%o) & 1.65 \\
\hline Available phosphorus (Olsen meth.) (ppm) & 52.50 \\
\hline $\begin{array}{l}\text { Exchangeable potassium (ammonium } \\
\text { acetate meth.) (ppm) }\end{array}$ & 352.00 \\
\hline Organic matter (Walkley Black meth.) (\%) & 3.13 \\
\hline Total limestone (\%) & 2.58 \\
\hline Active limestone (\%) & 1.40 \\
\hline $\mathrm{pH}\left(\mathrm{pH}\right.$ in $\left.\mathrm{H}_{2} \mathrm{O}\right)$ & 7.18 \\
\hline $\left.\mathrm{ECe}(\mathrm{dS} \mathrm{m})^{-1}\right)$ & 0.78 \\
\hline ESP & 0.80 \\
\hline $\mathrm{CEC}\left(\mathrm{BaCl}_{2}\right.$ meth $)(\mathrm{meq} / 100 \mathrm{~g}$ of dry soil $)$ & 31.61 \\
\hline \multicolumn{2}{|l|}{ Particle-size analysis $(\mathrm{mm})$ : } \\
\hline Total sand $(\%)$ & 20.94 \\
\hline $0.02>\varnothing>0.002$ & 44.00 \\
\hline$\varnothing<0.002$ & 35.06 \\
\hline \multicolumn{2}{|l|}{ Hydrologic properties: } \\
\hline Field capacity (field determ.) (\% d.w.) & 35.80 \\
\hline Wilting point (-1.5 MPa) (\% d.w.) & 18.40 \\
\hline Bulk density $\left(\mathrm{kg} \mathrm{dm}^{-3}\right)$ & 1.2 \\
\hline
\end{tabular}

Fertilizer were phosphorus and potassium applied (2 days before planting), using perphosphate and potassium sulphate respectively, whereas nitrogen was applied one week after emergence (that occurred about 15 days after planting), as ammonium nitrate and in two applications once a week. Just after planting, irrigation was applied whenever necessary to favour crop emergence.

Afterwards the crop was submitted to permanent irrigation and was watered whenever the rooting layer lost by evapotranspiration the fraction of water ranging from field capacity to a matric potential of $-0.1 \mathrm{MPa}$ by the volume required to restore it to field capacity.

All the farming practices adopted in Apulia (Italy) were applied through the potato cropping cycle; at harvest (on July $6^{\text {th }}, 2000$ ) the number of stems plant ${ }^{-1}$, the shoot dry matter, the production and number of tubers partitioned into 3 size classes $(<35 \mathrm{~mm}, 35-55 \mathrm{~mm} \mathrm{e}$ $>55 \mathrm{~mm}$ ) were determined. A sample of tubers/pot, taken randomly from marketable sizes, was then used for the determination of specific gravity, dry matter percentage, and starch content. All data were then submitted to the analysis of variance using the SAS software (SAS INSTITUTE INC.-USA), and the differences between the means were assessed by StudentNewman-Keuls' test. 


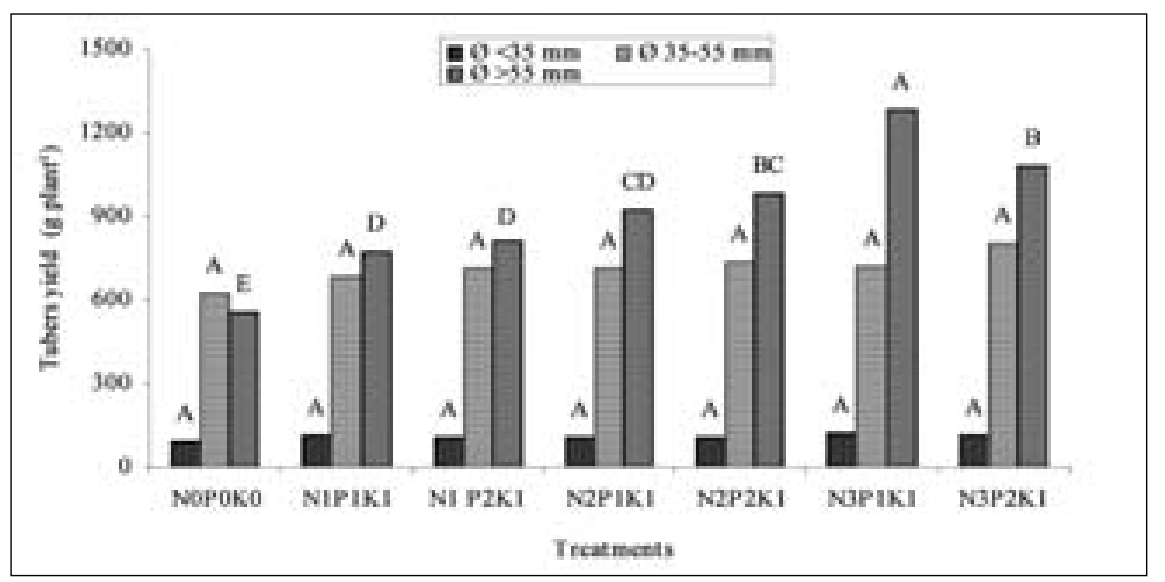

Figure 1. Effects of rates of NPK fertilizer on tuber yield of different size. For each effect considered, the values followed by the same letter are not significantly different, according to the SNK test at $\mathrm{P} \leq 0.01$.

\section{Results and discussion}

The results obtained show significant effects of different fertilizing formulae on potato yield and quality. As to the yield parameters the canopy was always more luxuriant as the fertilizing level was higher. In more fertilized crops a higher differentiation of stems per plant was observed, exceeding by $44 \%$ that of the unfertilized control. The shoot dry matter also increased with fertilization, notably with nitrogen (Tab. 2); this confirms what different Authors argue that nitrogen is a nutrient inducing a considerable vegetative growth. As to the number of tubers per plant, only the unfertilized crop differentiated the lowest number of tubers (16.7), whereas the highest number (19.6) was found for the crop fertilized by $\mathrm{N}_{2} \mathrm{P}_{2} \mathrm{~K}_{1}$ (Tab. 2) despite no significant difference was observed between applied rates. This does confirm that this plant may produce the same number of tubers just applying $100-200 \mathrm{~kg}$ $\mathrm{ha}^{-1}$ rather than $300 \mathrm{~kg} \mathrm{ha}^{-1}$ of nitrogen. This prevents any waste of fertilizer and is in agreement with the results reported Holliday et al. (1965),
Pritoni (1985), Casarini and Ranalli (1985), Martins et al. (1999). At the same time this is in compliance with the limits prescribed in potato protocols of different Italian regions that impose a rate not greater than $150-180 \mathrm{~kg} \mathrm{ha}^{-1}$.nitrogen. The highest total and marketable yields of tubers per plant have been observed at the two highest fertilizing levels $\left(\mathrm{N}_{3} \mathrm{P}_{1} \mathrm{~K}_{1}, \mathrm{~N}_{3} \mathrm{P}_{2} \mathrm{~K}_{1}\right)$, which are not statistically different so that the best treatments is shown to be $\mathrm{N}_{3} \mathrm{P}_{1} \mathrm{~K}_{1}$; the trend was similar for the mean weight of tubers. It is important to identify the production of tubers of optimal size for fresh consumption $(\varnothing 35-55 \mathrm{~mm}$ and $>55 \mathrm{~mm}$ ) as related to the change in the level of N, which mostly influences this parameter. With the various treatments, no difference was observed in terms of yield of tubers belonging to the two first size classes $(<35 \mathrm{~mm}$ and $35-55 \mathrm{~mm}$ ); what has increased with the fertilizing levels is the yield of tubers greater than $55 \mathrm{~mm}$, which reached $60 \%$ of total yield with the application of $300 \mathrm{~kg} \mathrm{ha}^{-1}$ of nitrogen and did not vary with the $\mathrm{P}$ levels, against $43 \%$ of the control (Fig. 1).

Table 2. Effects of different fertilizing formulae on potato quality parameters.

\begin{tabular}{|c|c|c|c|c|c|c|}
\hline \multirow[t]{2}{*}{ Treatments } & \multirow{2}{*}{$\begin{array}{c}\text { Stems } \\
\left(\mathrm{n} \text { plant }{ }^{-1}\right)\end{array}$} & \multirow{2}{*}{$\begin{array}{l}\text { Shoot dry } \\
\text { matter } \\
\left(\mathrm{g} \mathrm{plant}^{-1}\right)\end{array}$} & \multicolumn{4}{|c|}{ Tubers } \\
\hline & & & $\left(\right.$ g plant $\left.^{-1}\right)$ & $\left(\mathrm{n}\right.$ plant $\left.^{-1}\right)$ & $\begin{array}{l}\text { Mean weight } \\
(\mathrm{g})\end{array}$ & $\begin{array}{l}\text { Spec. gravity } \\
\left(\mathrm{g} \mathrm{cm}^{-3}\right)\end{array}$ \\
\hline $\mathrm{N}_{0} \mathrm{P}_{0} \mathrm{~K}_{0}$ & $1.6 \mathrm{C}$ & $34.6 \mathrm{D}$ & 1270.6D & 16.7B & $76.3 \mathrm{C}$ & $1.094 \mathrm{C}$ \\
\hline $\mathrm{N}_{1} \mathrm{P}_{1} \mathrm{~K}_{1}$ & $1.8 \mathrm{BC}$ & $65.0 \mathrm{C}$ & $1566.9 \mathrm{C}$ & $17.7 \mathrm{AB}$ & 89.1BC & $1.097 \mathrm{BC}$ \\
\hline $\mathrm{N}_{1} \mathrm{P}_{2} \mathrm{~K}_{1}$ & $2.0 \mathrm{~B}$ & $64.4 \mathrm{C}$ & $1628.7 \mathrm{C}$ & $18.6 \mathrm{AB}$ & 87.9BC & $1.101 \mathrm{~B}$ \\
\hline $\mathrm{N}_{2} \mathrm{P}_{1} \mathrm{~K}_{1}$ & $2.1 \mathrm{AB}$ & $74.3 \mathrm{BC}$ & 1729.2BC & $18.4 \mathrm{AB}$ & $94.7 \mathrm{~B}$ & $1.106 \mathrm{~B}$ \\
\hline $\mathrm{N}_{2} \mathrm{P}_{2} \mathrm{~K}_{1}$ & $1.9 \mathrm{BC}$ & $71.8 \mathrm{BC}$ & 1824.9B & $19.6 \mathrm{~A}$ & $93.0 \mathrm{~B}$ & $1.111 \mathrm{~A}$ \\
\hline $\mathrm{N}_{3} \mathrm{P}_{1} \mathrm{~K}_{1}$ & $2.1 \mathrm{AB}$ & $82.2 \mathrm{~B}$ & $2125.2 \mathrm{~A}$ & $19.1 \mathrm{AB}$ & $112.5 \mathrm{~A}$ & $1.102 \mathrm{BC}$ \\
\hline $\mathrm{N}_{3}^{3} \mathrm{P}_{2} \mathrm{~K}_{1}$ & $2.4 \mathrm{~A}$ & $98.1 \mathrm{~A}$ & 1994.1A & $19.2 \mathrm{AB}$ & $103.4 \mathrm{AB}$ & $1.100 \mathrm{BC}$ \\
\hline
\end{tabular}

For each effect considered, the values followed by the same letter are not significantly different, according to the SNK test at $\mathrm{P} \leq 0.01$. 


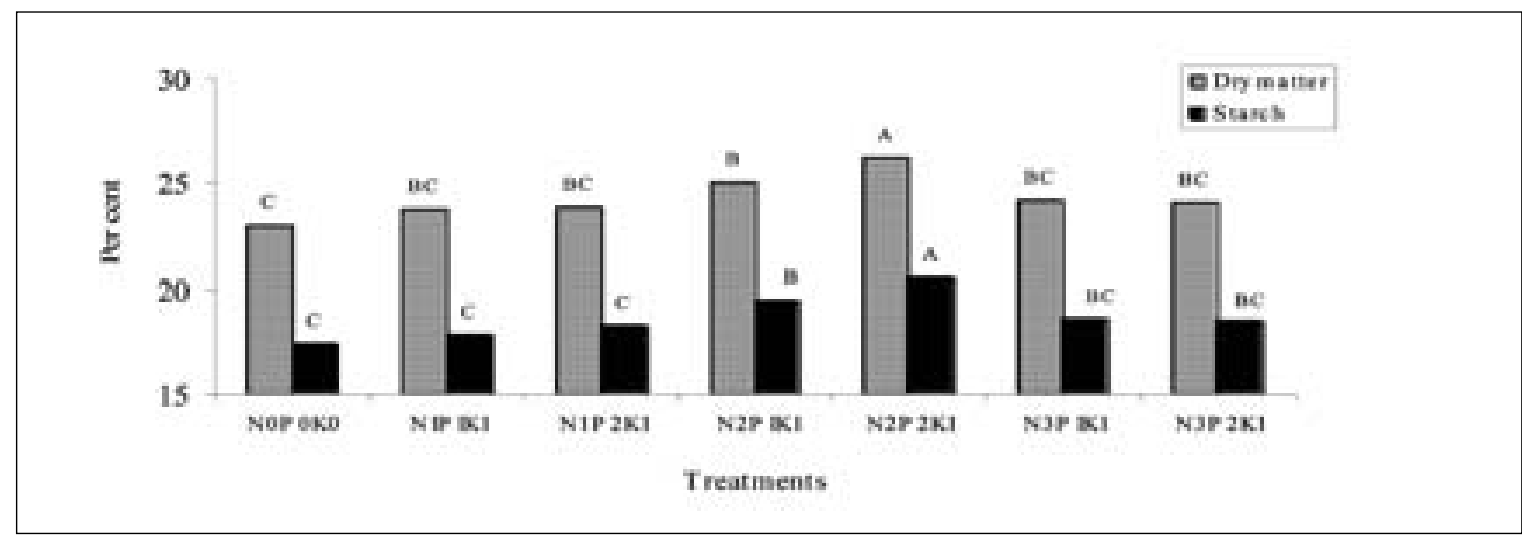

Figure 2. Effects of rates NPK fertilizer on the dry matter and starch content in potato tubers. For each effect considered, the values followed by the same letter are not significantly different, according to the SNK test at $\mathrm{P} \leq 0.01$.

In particular for the control $8 \%$ of the tubers produced from the crop were smaller than $35 \mathrm{~mm}, 49 \%$ ranging between 35 and $55 \mathrm{~mm}$ and $43 \%$ greater than $55 \mathrm{~mm}$. For the crops that had received the lowest nitrogen level $\left(\mathrm{N}_{1}\right), 7 \%$ of produced tubers were below $35 \mathrm{~mm}, 44 \%$ between 35 and $55 \mathrm{~mm}$ and $49 \%$ greater than $55 \mathrm{~mm}$.

With $200 \mathrm{~kg} \mathrm{ha}^{-1}$ of nitrogen, the production of tubers of $35 \mathrm{~mm}$ was $6 \%$; the tubers between 35 and $55 \mathrm{~mm}$ were $41 \%$ and those greater than $55 \mathrm{~mm}, 53 \%$. Lastly at the highest nitrogen rate, the yield values for the three size classes were 6-37 and 57\% respectively.

Figure 1 shows that nitrogen favours the formation of tubers above $55 \mathrm{~mm}$, thus confirming what is reported by Gravoueille (1987) and Tesi (1998). As to phosphorus, considering the applied rates, it had no sharp influence on tuber yield, in agreement with what is observed by most Authors who identify the optimal rate between 80 and $150 \mathrm{~kg} \mathrm{ha}^{-1}$ of phosphorus (Pritoni, 1985).

Tuber specific gravity show, as expected a positive correlation with the dry matter percentage. Both parameters increased shifting from the control to the $\mathrm{N}_{2} \mathrm{P}_{2} \mathrm{~K}_{1}$ (respectively from 1.09 to $1.11 \mathrm{~g} \mathrm{~cm}^{-3}$ for the former and from 23.0 to $26.2 \%$ for the latter) and decreased at the highest $\mathrm{N}$ level, without any difference being observed with the change in the $\mathrm{P}$ rate. The highest starch percentage $(20.5 \%)$ was also observed in the crop fertilized by $\mathrm{N}_{2} \mathrm{P}_{2} \mathrm{~K}_{1}$ (Tab. 2 and Fig. 2).

\section{Conclusions}

1. The experimental results on the number of stems per plant and on the shoot dry matter show that the plant growth seems poor when no fertilization is applied or when applying $100 \mathrm{~kg} \mathrm{ha}^{-1}$ of nitrogen; therefore it is recommended to apply not less than $200 \mathrm{~kg} \mathrm{ha}^{-1}$ to ensure an optimal crop growth.

2. Yield and yield components increase with the application of nitrogen fertilizer and do not change when applying high rates of phosphorus.

3. Tubers to be exported to the German market must be of with the appertain of extra and top class; the best results are obtained with the application of $300 \mathrm{~kg} \mathrm{ha}^{-1}$ of nitrogen, without any variation with the rates of phosphorus applied.

4. The tubers with the highest specific gravity and starch content values are obtained when applying respectively 200 and $50 \mathrm{~kg} \mathrm{ha}^{-1}$ of nitrogen and phosphorus.

\section{References}

Bianco V.V. 1990. Ambiente, mezzi agronomici e qualità dei prodotti orticoli. Riv. di Agron., 24:81-131.

Gravoueille J.M. 1987. Fertilization et qualité de la pomme de terre. La pomme de Terre Française, 442:213-220.

Grignani C., Bassanino M., Sacco D., Zavattaro L. 2003. Il bilancio degli elementi nutritivi per la redazione del piano di concimazione. Riv. Di Agron. 37, 2:155-172. 
Kunkel R., Holstad N. 1972. Potato chips colour specific gravity and fertilization of potatoes with N-P-K. Am. Potato J., 49:43-62.

Leszcynski W., Lisinska G. 1988. Influence of nitrogen fertilization on chemical composition of potato tubers. Food Chem., 28:45-52.

Marshner H., Krauss A. 1980. Correlations between potassium content and quality of potatoes. Kartoffelbau, 31 (2):65-67. Field Crop Abstr., 34:4728.
Muller K. 1988. Potassium fertilization of potatoes. Kartoffelbau, 39, 3:102, 104-105.

Piazza R., Venturi G. 1973. Effetti di azoto, fosforo e potassio su patata precoce. Riv. Di Agron., 7:179-188.

Shevchenko L.A., Sidoreko V.P. 1976. Effect of periodical application of phosphorus fertilizer on yield and quality of potatoes. Kartopl. Resp. Mizhvid. Temat. Nauk. Zb., 7:56-59. Field Crop Abstr., 30:382. 